\title{
Chapter 20 \\ Rural Landscape Conservation in Japan: \\ Lessons from the Satoyama Conservation \\ Program in Kanagawa Prefecture
}

\author{
Osamu Koike
}

\begin{abstract}
Japanese call rural landscapes 'satoyama.' 'Sato' means village and 'yama' means hill or forest. Satoyama in the past produced much of the food, wood for fuel, timber, and water for communities. However many satoyama have rapidly deteriorated due to industrialization and urbanization. It was in the 1990s that people in general and scientists began to recognize the multiple benefits of satoyama landscapes in Japan. This led to the proliferation of satoyama conservation groups across Japan at the turn of the century. However, it is difficult for local action groups to rehabilitate devastated farmlands and forests through their own efforts alone. It requires policy measures to encourage citizen engagement in satoyama conservation programs. In this paper the author addresses governance issues in rural landscape conservation, referring to the case of the satoyama conservation program in the Kanagawa region.
\end{abstract}

Keywords Citizen engagement $\bullet$ Local government $\bullet$ Rural landscape $\bullet$ Satoyama

\subsection{Crisis of Satoyama Landscapes in Japan}

Japanese people call rural landscapes 'satoyama.' 'Sato' means village and 'yama' means hill or forest. Takeuchi (2003) defines 'satoyama' as the 'secondary woodlands and grasslands adjacent to human settlements.' Farmers in satoyama areas have been living in harmony with nature for centuries, and such areas make the landscapes of rural communities multi-functional. 'Landscape' is defined as 'an area, as perceived by people, whose character is the result of the action and interaction of natural and/or human factors,' according to the European Landscape Convention. Satoyama, meanwhile, is defined by a study team from the United Nations University as a

\footnotetext{
O. Koike $(\bowtie)$

Graduate School of International Social Sciences, Yokohama National University, Yokohama, Japan e-mail: okoike@ynu.ac.jp
} 
Japanese term for landscapes that comprise a 'mosaic of different ecosystem types including secondary forest, agricultural lands, irrigation ponds, and grasslands, along with human settlements' (Duraiappah and Nakamura 2012: 3). For a long time, Japanese people have considered satoyama landscapes to be a symbol of the traditional Japanese lifestyle and a spiritual home for the population.

In Japan, satoyama occupy nearly $40 \%$ of the total landmass. Satoyama in the past produced much of the food, wood for fuel, timber, and water for communities. However many satoyama have deteriorated rapidly due to industrialization and urbanization. Farmers use chemical fertilizers instead of natural composts; people use electricity and gas instead of firewood. A decline in the economic value of agriculture and forest products has accelerated rural-urban migration of younger generations and the aging of populations in rural areas (Duraiappah and Nakamura 2012:5). In the urban fringes, housing development encroaches on the rural landscapes, which results in deterioration of the ecosystem and biodiversity in these areas.

It was in the 1990s that people in general and scientists began to recognize the multiple benefits of satoyama landscapes in Japan (Takeuchi 2003). The 'slow food' or 'slow life' movement inside and outside the country had partially contributed to the reappraisal of satoyama in terms of food security, therapy, and environmental education. It was biologists that emphasized the rich biological diversity of satoyama areas. This led to the proliferation of satoyama conservation groups across Japan at the turn of the century.

\subsection{Citizens' Actions for Satoyama Conservation}

In environmental conservation, the role of government has been widely recognized based on the discussion presented in the 'Tragedy of the Commons' (Hardin 1968). Controlling greenhouse gas emissions, preserving marine resources such as whales and coral reefs, and establishing national parks for wild animals are all examples of government intervention. In rural landscape conservation, however, smaller populations mean that political action is not guaranteed, even though rural landscapes contain valuable resources such as beautiful scenery, cultural heritages, and biodiversity (Swaffield and Primdahl 2010). It requires a strong political commitment to take policy measures for conserving rural landscapes, such as land-use regulation, direct income support for working farmers, and allocation of budgets for non-agricultural functions including the conservation of historical and cultural heritages. If no positive action is taken, it will result in the deterioration of rural landscapes in the near future.

In Japan, citizens facing the decline of rural landscapes have taken action to regenerate abandoned farmlands and forests before government intervention. As agricultural land and forest in rural areas are private property, national and local governments find it difficult to provide direct support for rural communities. For better or for worse, this encourages collaborative actions between farmers and community members for the conservation of rural landscapes. Such collaboration is deeply rooted in the historical heritage of rural governance in Japan. 
In the pre-modernization era, farmers in rural villages developed a system of 'common property' for the common use of water, grass, wood, and timber in their communities. This type of 'common pool of property' is called 'iriaichi' in Japanese. Margaret McKean (1992) notes that 'well organized communities of co-owners are capable of protecting and managing their property quite well' (McKean 1992, p. 253). Even though the system of iriaichi has disappeared in contemporary Japan, rural community members keep a mindset of 'mutual help' as in the past. It enables the lending and borrowing of abandoned farmlands among the community members outside of traditional property ownership. In the process of landscape conservation, urban citizens have also joined in the conservation efforts, organizing voluntary action groups. As a result, various patterns of 'collaboration' or 'partnership' have developed among farmers and civic organizations across the country.

\subsection{Governmental Policies for Satoyama Conservation}

It was in the mid-90s that a renewed and growing interest revived the traditional rural landscapes of satoyama in Japan (Duraiappah and Nakamura 2012, p. 2). A trigger was the Earth Summit in Rio de Janeiro of 1992 that discussed sustainable development in the world. After the Rio Declaration, Japanese national and local governments began looking at policy for rural areas in terms of environmental conservation. However policy actions remained superficial and piecemeal. In 1994, the national government established the Basic Environment Plan and referred to the need for satoyama conservation officially. It described the satoyama landscape as an area featuring substantial secondary nature where wild animals and humans can live together. It stated, 'the natural environment of this area is created through human interventions such as farming and forestry, and it is what Japanese people have long imagined as their idyllic landscape. In order to conserve the coppices, rice paddies, and irrigation ponds of satoyama landscapes, some action by citizens and public support are necessary' (Takeuchi 2003, p. 11).

In the National Biodiversity Strategy of 1995, the government also made the conservation of ecosystems in Japan a priority. However the strategy did not contain the term satoyama. It was the New National Biodiversity Strategy of 2003 that defined satoyama as an ecosystem that preserves biological diversity. Based on the new strategy, the Ministry of Environment (MOE) launched the Satoyama Conservation and Rehabilitation Model Program in 2004. In 2008, the government enacted the Basic Law on Biodiversity that defined satoyama areas eligible for biodiversity conservation. In 2010 the Ministry of Environment unveiled the Satoyama Conservation and Utilization Action Plan to provide a guideline for local government on how to conserve satoyama areas. It is the Ministry of Environment that has been the most dynamic actor in the conservation of satoyama areas. The Ministry advocates the 'Satoyama Initiative' in international meetings on biodiversity, based on the experiences in Japan. Finally the government of Japan officially called for the promotion of the 'Satoyama Initiative' at the COP 10 biodiversity meeting in Nagoya in October 2010 (Takahashi 2012). 
Later the Ministry of Agriculture, Forestry and Fisheries (MAFF) joined the satoyama program. The Basic Law on Food, Agriculture, and Rural Areas of 1999 defined the multiple functions of farmlands, such as maintaining biodiversity and disaster prevention. However achievement of these newly defined functions was not initially linked to the conservation of satoyama. Instead MAFF introduced a system of direct income support payments for farmers operating their farms as businesses to emphasize the multi-functionality of agriculture as in the EU. MAFF believed that a direct payment would motivate farmers and lead to a reduction in the number of abandoned cultivated lands in the hilly and mountainous areas (MAFF 2011). On the other hand, the Ministry of Land, Infrastructure, Transport and Tourism (MLIT) used satoyama to reintegrate agricultural space into urban areas so as to establish multifunctional green spaces (Yokohari et al. 2010). Meanwhile, the Ministry of Internal Affairs and Communications (MIC) also joined the race. MIC assisted local governments to promote rural development programs in satoyama areas, such as eco-tourism. However there is no single agency beyond the ministries mentioned above that is responsible for integrated satoyama conservation programs (Takahashi 2012). This has resulted in superficial and fragmented public programs for satoyama conservation in national government.

Lack of positive, integrated policy measures on satoyama conservation at national level pushed the local action groups toward direct collaboration with local government. In the first decade of the 2000s, municipal and prefectural governments decided to enact local bylaws to conserve rural landscapes. In 2000, the City Government of Kouchi enacted a local bylaw that aimed to conserve satoyama areas in Kouchi city. It designated satoyama conservation areas for disaster relief to protect citizens from tsunami tidal waves. In 2003, Chiba Prefectural Government enacted the Satoyama Bylaw to support citizens' voluntary action to conserve community forests in the Chiba region. It was followed by Kanagawa Prefecture in 2007. Kanagawa's Satoyama Conservation Bylaw aims to rehabilitate, conserve, and develop satoyama areas through the collaboration of farmers, landowners, local action groups and municipal and prefectural governments.

In 2011-2013, the author conducted research on the satoyama conservation programs of the Kanagawa prefecture government. It revealed a number of both achievements and challenges in the conservation of rural landscapes in the Kanagawa region.

\subsection{Satoyama Conservation in Kanagawa Prefecture}

Kanagawa prefecture is located to the south of the Tokyo Metropolis and, with neighboring prefectures, makes up the National Capital Region. The eastern part of Kanagawa, which includes Yokohama City and Kawasaki City, is heavily urbanized. The western part, on the other hand, is mountainous and rich in nature. Rural satoyama areas have been protected from development, being located in the hinterlands, or comprising part of Quasi-National Park Reserved Areas. These areas are 
designated either as Urbanization-Restricted Areas or Agriculture Promotion Areas. However farmlands and forests in the Kanagawa region are rapidly decreasing due to urbanization and industrial development. In the areas closest to the urban districts the encroachment of housing and manufacturing damages the landscape of rural areas. Inside satoyama areas aging farmers give up farming and forestry and their children move away to work in offices. This results in the devastation of rural landscapes. To save satoyama areas from this deterioration the Kanagawa Prefectural Government enacted a bylaw in 2007, and this was followed by the Satoyama Conservation Action Plan in 2009.

The Satoyama Conservation Bylaw aims to enrich people's wellbeing by developing the multiple functions of satoyama in Kanagawa. Satoyama have a multifaceted significance, providing seasonal scenery, biodiversity, cultural heritage, fresh air, safe food, disaster relief, etc. The bylaw underscores the role of community and municipal government in the conservation of satoyama landscapes. It is the prefectural government that selects 'Satoyama Conservation Areas' and accredits 'Satoyama Conservation Partnership Agreements' between landowners and local action groups. The prefectural government provides financial and technical assistance for local action groups, who purchase grass cutters and chainsaws using subsidies. The Agriculture Division of Kanagawa Prefectural Government hosts programs to raise public awareness of satoyama among people of different generations, including farming experience programs for school children, satoyama symposiums, and other initiatives.

In the Action Plan the prefectural government set the goal of selecting 16 conservation areas and 20 partnership agreements by 2013. By 201213 areas had been designated as Satoyama conservation sites and 14 local action groups had established Satoyama Conservation Partnership Agreements to engage in satoyama conservation activities (see Fig. 20.1). They range from the smallest Ishikawa-Maruyama area (12 ha) to the largest Kuno area (2,800 ha). The larger areas include mountain forests, while farmlands are relatively modest in size and divided into small plots. Some mountain forests are the common property of landowners.

Based on the established partnership agreements, action groups borrow the abandoned farmlands and forest from the landowners to rehabilitate them for use (see Fig. 20.2). Besides the rehabilitation of farmlands and forest, local action groups have utilized the resources of satoyama landscapes in different ways as shown in Table 20.1. The most popular activity is environmental education. Local action groups invite school teachers and students to their satoyama areas to provide a 'field' for the study of nature and biodiversity. There is a growing interest in a 'hands-on' approach to environmental education among school teachers, and satoyama offer them the ideal opportunity for this. In some areas action groups hold various events with the local neighborhood organizations to teach traditional knowledge and cultural heritage such as traditional cooking, toys, and crafts to small children. In the Kuno area of Odawara City the action group invites children and their parents living in the city center to plant soba (buckwheat) as shown in Fig. 20.3. After planting the soba a member of the action group plays educational nature games with the children to teach them the various species of insects. 


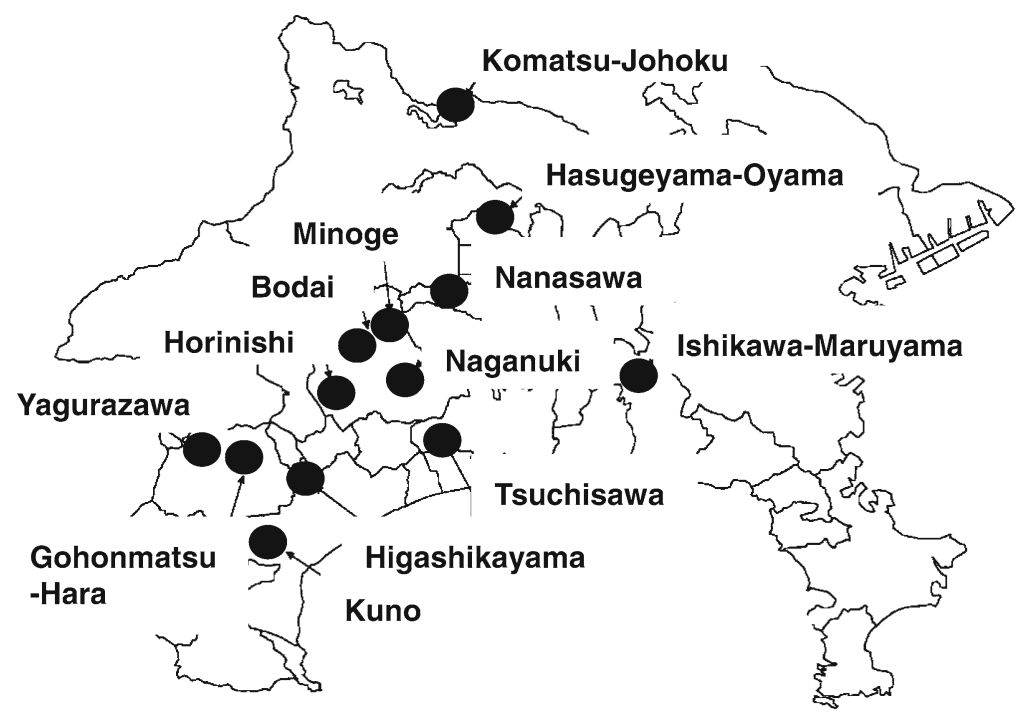

Fig. 20.1 Map of satoyama conservation areas (as of 2012)

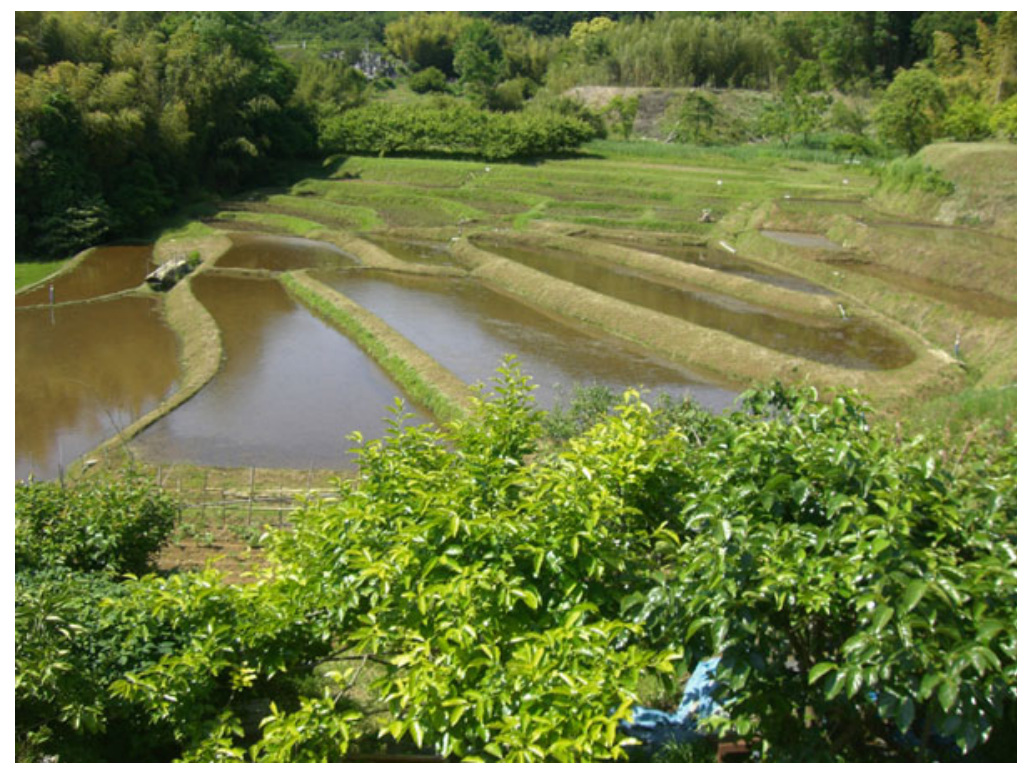

Fig. 20.2 A rehabilitated terraced rice field in Naganuki (Hadano City)

Secondly, members of action groups know that satoyama are often used for recreation. Satoyama provide opportunities for such pursuits as walking, hiking, birdwatching, camping, and fishing. Some action groups work to provide facilities such as benches, signboards, and parking lots to welcome visitors. A group in 
Table 20.1 Major activities in the satoyama conservation areas

\begin{tabular}{|c|c|}
\hline Area & Major activities \\
\hline Bodai & $\begin{array}{l}\text { Rehabilitation of farmland (terraced rice fields) and forest; food education } \\
\text { (cooking local foods); farming experience program for urban } \\
\text { consumers in collaboration with the COOP Kanagawa }\end{array}$ \\
\hline Gohonmatsu-Hara & $\begin{array}{l}\text { Rehabilitation of farmland and forest; education activities for sustainable } \\
\text { development; chrysanthemum festival }\end{array}$ \\
\hline Higashikayama & $\begin{array}{l}\text { Rehabilitation of farmland and forest; farming experience program; colza } \\
\text { flower festival; biodiversity survey; social education }\end{array}$ \\
\hline Horinishi & $\begin{array}{l}\text { Rehabilitation of irrigation, farmlands, and forest; rice farming experience } \\
\text { program }\end{array}$ \\
\hline Ishikawa-Maruyama & $\begin{array}{l}\text { Preservation of fireflies; conservation of farmlands in hilly terrain; } \\
\text { biodiversity survey in collaboration with elementary school }\end{array}$ \\
\hline Komatsu-Johoku & $\begin{array}{l}\text { Woodlands conservation; preservation of fireflies; farming experience } \\
\text { program; ancient route restoration; cosmos festival }\end{array}$ \\
\hline Kuno & $\begin{array}{l}\text { Rehabilitation of farmland and forest; biodiversity survey; farming (soba } \\
\text { planting) experience program; mountain trails rehabilitation }\end{array}$ \\
\hline Minoge & Rehabilitation of farmland and forest; farming experience program \\
\hline Naganuki & $\begin{array}{l}\text { Rehabilitation of farmland (terraced rice fields) and forest; fruit farming } \\
\text { experience program; cooking class using local foods }\end{array}$ \\
\hline Nanasawa & $\begin{array}{l}\text { Rehabilitation of farmland and forest; landscape (scenery) conservation; } \\
\text { charcoal production; micro-hydroelectric power generation }\end{array}$ \\
\hline Tsuchisawa & $\begin{array}{l}\text { Rehabilitation of irrigation; conservation of woodlands; biodiversity survey } \\
\text { in collaboration with elementary school and university; cooking class; } \\
\text { environmental education; provision of playgrounds for children }\end{array}$ \\
\hline Yagurazawa & $\begin{array}{l}\text { Rehabilitation of farmland and forest; promotion of nature education; } \\
\text { chrysanthemum festival; health promotion }\end{array}$ \\
\hline
\end{tabular}

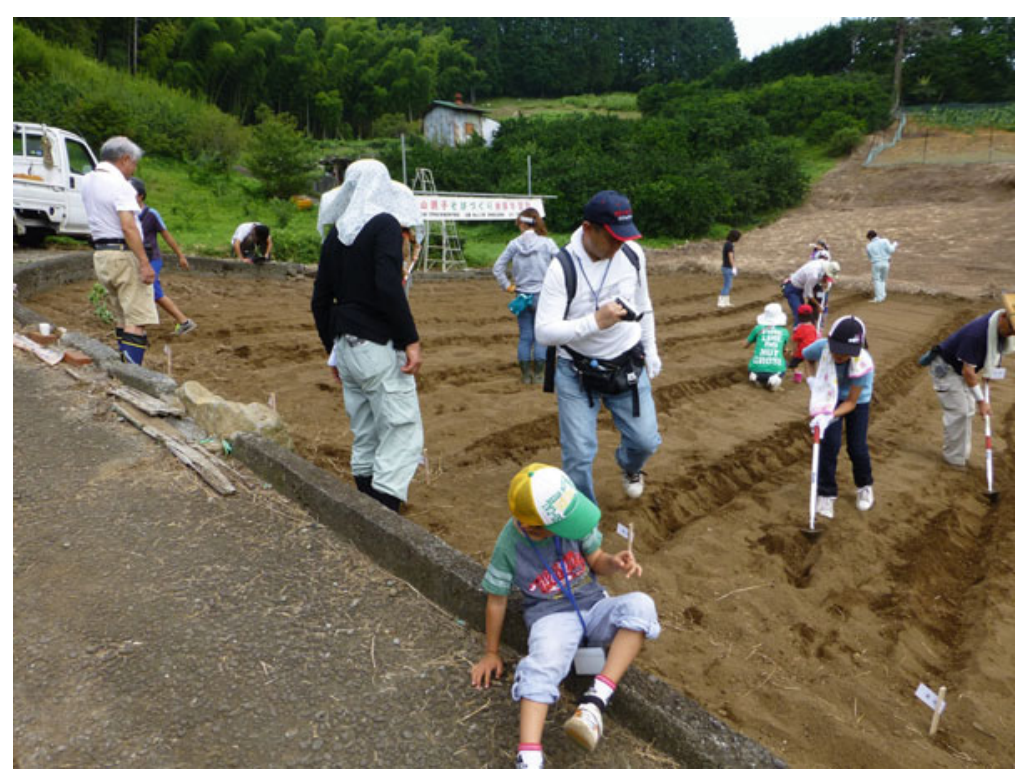

Fig. 20.3 Seeding of soba by children in Kuno (Odawara City) 
Komatsu-Johoku restored ancient trails for tourists; another group in Kuno established a trail up Mt. Myojo. Several groups host flower festivals and cultural events for visitors from urban areas. These actions are sustained by the emotion that the beautiful scenery of satoyama inspires in the local residents; they are the pride of the community. Therefore action groups plant trees and restore devastated terraced rice fields to rehabilitate landscapes.

The third facet of satoyama is health and welfare; walking around satoyama cleanses body and soul. Farming and forestry are beneficial for depression, and there is a growing interest in 'agri-therapy' and 'forest therapy' among health policy professionals. Consequently, some action groups use farmlands and forest to promote health and welfare. In the Yagurazawa area of Minami-Ashigara City, the local action group invites patients of a mental hospital to engage in farming activities.

The most striking finding is that a variety of conservation activities are "homegrown.' Municipal and prefectural governments provide only limited subsidies and technical advice for action groups; if necessary, action groups organize seminars and invite lecturers from outside. It is notable that a horizontal, regional network of satoyama conservation has developed in Kanagawa prefecture.

\subsection{The Way Forward}

Of course it is too early to evaluate the outputs and outcome of satoyama conservation programs in Kanagawa. The rehabilitation and conservation of satoyama areas in Kanagawa remain in their early stages at best. Accordingly it is better to discuss the challenges for the way forward.

First, Japan's aging population and dwindling younger generation are quite serious issues in satoyama communities. In mountainous areas farmers face the problem of increasing wild boar and deer populations that eat agricultural products, and it is difficult for the senior citizens to protect farmlands from these wild animals. It requires the government to take positive policy measures to involve younger generations in the conservation of satoyama landscapes.

A second challenge is the fact that intergovernmental cooperation is necessary for successful satoyama conservation. Vertically segmented public administration and fragmented programs impede integrated community actions for conservation. In this regard the role of prefectural government is quite important. As individual municipal governments lack incentives to cooperate, it is the prefectural government that can initiate the regional cooperation of municipalities.

The third is financial support for local action groups. Most farmers in the satoyama areas do not engage in for-profit agricultural production any more. Their agriculture is more a kind of self-sufficiency. They produce rice and vegetables for the consumption of their families, and feel joy in welcoming children to the farmland to teach them how to live with nature. Therefore, rather than seeking direct payments for income support, they want local government to reform legal and institutional frameworks to make their voluntary actions more effective. For example, 
under current land use regulations it is difficult for them to construct a rest room at the corner of farmland. Needless to say, it is important to develop measures to raise funds for these positive activities, and it will therefore be possible for local action groups to engage in business to acquire financial resources. In the process private companies will be able to engage in the conservation of forests in order to demonstrate their 'corporate social responsibility' (CSR). In this case, local governments should introduce strategic measures such as 'carbon offset credit' to attract private enterprises to contribute to satoyama conservation.

Finally, both national and local governments should seek international cooperation on satoyama conservation. It is possible to link the practices of satoyama conservation with the Education for Sustainable Development (ESD) project by the United Nations University/UNESCO and the 'Satoyama Initiative' promoted by the United Nations. Furthermore, it is highly recommended for Japanese local governments to work with European local governments that promote landscape conservation under the European Landscape Convention of 2000 (Dejeant-Pons 2011).

\subsection{Concluding Remarks}

Farmlands and forests in satoyama areas are individually owned private properties. However, faced with the issues of an aging population and an increase in abandoned farmlands and forests, conservation groups organize to rehabilitate their satoyama collectively. The groups, comprising farmers, landowners, and community members, do so not only to promote their personal interests but for the well-being of future generations. In the past, Japanese rural communities had a system of common property management named 'iriaichi.' The iriaichi system has disappeared from Japan in the process of agricultural modernization and land reform, and has led to an increase in farms operated as businesses. However, the challenge now facing satoyama conservation is not to attempt to revive this old system of common property management. As Kanagawa's satoyama conservation programs demonstrate, the orientation is instead toward a new mode of community-based conservation based on collaboration by landowners and local action groups. The bylaws encourage common use of privately owned farmlands for the rehabilitation and conservation of rural landscapes.

It should be noted that both community members and action groups work together to keep these landscapes beautiful for future generations. They do not demand an income support program from the government, rather they require the revision of national laws to make the best use of their properties. Current agricultural policy is premised on promoting agricultural industrialization and 'commercialization.' However most farmers in the satoyama areas are not engaged in farming as a business and their main source of income is not from the farming. They are simply individuals who like the satoyama lifestyle and living with nature.

To support the activities of local action groups in satoyama areas it seems necessary to create a strong network of professionals. In the case of environmental 
education, for example, school teachers and the parents of school children would welcome university professors to provide scientific knowledge on the subject. Meanwhile, where health promotion is concerned, a network of medical doctors, schools of medicine, public health centers, and hospitals would enhance the effective use of satoyama properties for public health promotion.

From a sociological perspective, civic engagement in satoyama conservation will enhance the so-called 'social capital' of urban populations (Putnam 2000). Working together with farmers, urban dwellers can feel and understand the meaning of community ties and 'quality of life' in a material society.

This leads us back to the debate on the responsibility of government in the provision of public goods. People in satoyama think that these landscapes are public goods necessary for the well-being of mankind in terms of 'safety and security.' The author expects a new mode of civic governance will develop through a combination of community-based conservation and local government policy measures to develop the multi-functionality of satoyama landscapes. It will take on a different shape from western countries due to the influence of traditional values inherent in the sustainable lifestyle of Japan.

Open Access This article is distributed under the terms of the Creative Commons Attribution Noncommercial License which permits any noncommercial use, distribution, and reproduction in any medium, provided the original author(s) and source are credited.

\section{References}

Dejeant-Pons M (2011) The European landscape convention: from concepts to rights. In: Egoz S, Makhzoumi J, Pungetti G (eds) The right of landscape: contesting landscape and human rights. Ashgate Publishing, Burlington

Duraiappah AK, Nakamura K (2012) The Japan satoyama satoumi assessment: objectives, focus and approach. In: Duraiappah AK et al (eds) Satoyama-satoumi ecosystems and human wellbeing: socio-ecological production landscapes of Japan. United Nations University Press, Tokyo

Hardin G (1968) The tragedy of the commons. Science 162:1243-1248

Ministry of Agriculture, Forestry and Fisheries (MAFF) (2011) FY 2011 annual report on food, agriculture, and rural areas in Japan: summary. http://www.maff.go.jp/j/wpaper/w_maff/h23/ pdf/e_all.pdf. Accessed 29 Aug 2013

McKean M (1992) Success on the commons: a comparative examination of institutions for common property resource management. J Theor Polit 4(3):247-281

Putnam RD (2000) Bowling alone: collapse and revival of American community. Simon and Schuster Paperbacks, New York

Swaffield S, Primdahl J (2010) Globalisation and local agricultural landscapes: patterns of change, policy dilemmas and research questions. In: Primdahl J, Swaffield S (eds) Globalisation and agricultural landscapes: changing patterns and policy trends in developed countries. Cambridge University Press, Cambridge 
Takahashi T (2012) What and how effective have the main responses to address changes in satoyama and satoumi been? In: Duraiappah AK et al (eds) Satoyama-satoumi ecosystems and human well-being: socio-ecological production landscapes of Japan. United Nations University Press, Tokyo

Takeuchi K (2003) Satoyama landscapes as managed nature. In: Takeuchi K et al (eds) Satoyama: the traditional rural landscape of Japan. Springer, Tokyo

Yokohari M, Amatim M, Bolthouse J, Kurita H (2010) Restoring agricultural landscapes in shrinking cities: re-inventing traditional concepts in Japanese planning. In: Primdahl J, Swaffield S (eds) Globalisation and agricultural landscapes: changing patterns and policy trends in developed countries. Cambridge University Press, Cambridge 